\title{
THE INDIVIDUAL TRANSPORT MOBILITY GAP (ITMG) AS AN OBSTACLE ON THE ROAD TO HIGHER RATES OF PUBLIC TRANSPORT USE
}

\author{
Stefan Bongard \\ Ludwigshafen University of Business and Society, \\ Ludwigshafen am Rhein, Germany, stefan.bongard@hwg-lu.de
}

\begin{abstract}
Research purpose. The call for higher rates of public transport usage seems reasonable and understandable, given the growing impact of climate change and the high burden of heavy traffic, especially on urban transport structures. A course of Bachelor's degree students in Logistics explored the issue of satisfaction with individual transport mobility, formulating the hypothesis that there must be a striking difference in the quality behind the use of a private car versus the use of public transport. The hypothesised difference in perceived quality between the two modes of transport was called the individual transport mobility gap (ITMG).
\end{abstract}

Design/Methodology/Approach. The ITMG was considered from the perspective of people who mainly use a car (car users) and who mainly use public transport (public transport users). Both groups were asked how they rate their preferred means of transport and how they rate the alternative mode of transport using an online questionnaire. The survey can be accessed online at: https://fhludwigshafen.eu.qualtrics.com/jfe/form/SV_6JOoxNvlSVxsdDv.

Findings. The results of the study confirmed the hypothesis that there is a substantial perceived gap with an ITMG value of 4.0 between using a car versus using public transport for people who primarily use a car. In contrast, the ITMG value for public transport users was only 0.8 .

Originality/Relevance/Practical Implications. The originality of this approach lies in surveying satisfaction with a mode of transport at a highly aggregated level rather than at the level of individual quality factors, such as punctuality or flexibility. ITMG is defined in this study as a valuable metric that provides a basis for comparison. This quantitative metric can in turn be used to determine the effectiveness of measures to increase usage rates of public transport. The study also provides practical findings by making available its database to other researchers for further evaluation purposes. The study also contributes to scholarly and public discourse on how to effectively reduce the satisfaction gap in the use of private cars versus public transport, thus resulting in improved outcomes for the environment and society.

Keywords: Action-Based Teaching; Empirical Case Study; Mobility Management; Motorised Individual Transport; Public Transport.

JEL codes: A23; R40.

\section{Introduction}

Although there are a variety of arguments and motivations for increasing the use of public transport, two examples from early 2020 will help to illustrate how the use of public transport might successfully be encouraged.

First, Luxembourg was the first country in the world to introduce free public transport, which went into effect on 29 February 2020. The stated aim is to encourage people to use public transport instead of using their cars (Frankfurter Allgemeine Zeitung (FAZ), 2020).

Second, the German Bundestag approved two draft laws presented by Federal Minister Andreas Scheuer to improve public transport on 1 January 2020. The laws will massively increase federal funding for public transport in Germany, with the goal of making it easier to switch to public transport services such as bus, tram or train. Funding is allocated for investments in vehicles, subsidies for ticket prices and infrastructure improvements, ranging from new construction to renovation (BMVI, 2020). 
On the one hand, this use of public funds to finance public transport appears convincing, because public transport offers clear economic and environmental advantages over private transport by car. The Berliner Verkehrsbetriebe (BVG), for example, found that, in 2017, public transport used an average of $3.3 \mathrm{~L}$ of diesel per person per $100 \mathrm{~km}$. All bus lines, days of the week and times of day were taken into account in this calculation (Berliner Morgenpost, 2018). With a diesel price per litre at $1.16 €$, this would mean that it costs $3.83 €$ to transport one person for $100 \mathrm{~km}$. The corresponding $\mathrm{CO}_{2}$ emissions would have to be indicated as a tank-to-wheel value, with $8.75 \mathrm{~kg} \mathrm{CO} / 100 \mathrm{~km}\left(\mathrm{CO}_{2}\right.$ coefficient: 2.650; Schallaböck $\&$ Carpantier, 2012).

In contrast, the average fuel consumption in 2017 for cars and station wagons was $7.4 \mathrm{~L}$ per $100 \mathrm{~km}$. With reference prices for petrol of $1.36 € / \mathrm{L}$ and diesel of $1.16 € / \mathrm{L}$, this would mean that private car transport cost $10.06 €$ per $100 \mathrm{~km}$ (for petrol) or $8.58 €$ (for diesel) per $100 \mathrm{~km}$ per person. The corresponding $\mathrm{CO}_{2}$ emissions (tank-to-wheel) would then be $17.54 \mathrm{~kg} \mathrm{CO}_{2}$ for petrol or $19.61 \mathrm{~kg}$ for $\mathrm{CO}_{2}$.

On the basis of these figures, one could now conclude that the costs and emissions of using a private car are more than double those of using public transport, which would thus justify the allocation of public funds for public transport (a caveat here is that this calculation is based on a private car being used by one person only, not accounting for potentially multiple passengers).

The modal split in passenger transport between public transport and private cars has remained almost unchanged in the recent years. If non-motorised passenger transport (pedestrians and bicycles) is included in the volume of transport, motorised individual transport dominates with a share of about $75 \%$ and is thus clearly ahead of more environmentally friendly means of transport (pedestrians, bicycles, rail and public road transport), which together amount to about $20 \%$. These figures have remained roughly stable since 2003 (Umweltbundesamt, 2020).

This leads to two important questions: First, will the additional expenditures of public investment in public transportation in both Luxembourg and Germany ensure that the modal split moves in favour towards public transport? Second, why has the modal split remained so unchanged over the years? Although the first question must remain unanswered (the result lies in the future), the present work is devoted to the second question.

In the Quality Management course, students learn basic definitions, concepts and methods. According to a common definition, quality is the degree of agreement between a quality requirement (from the customer's perspective) and the performance delivered (by the company; Zollondz, 2006; Brüggemann \& Bremer, 2015. Typically, the quality requirement consists of a number of individual requirements, and performance is made up of a number of individual results. By evaluating and aggregating the individual factors, the degree of quality can be measured. A number of things can be problematic here, such as the sometimes high number of relevant factors, the aggregation of different scale levels or the weighting of individual factors.

One approach to avoid these problems is by focusing on a single assessment factor. The so-called Net Promoter Score, which was developed by Bain \& Company, a Boston-based consulting firm, is relevant in this context (Bain \& Company, 2011). The core of this approach is a single question about the probability of recommending a product or service to a friend or colleague, on a scale of 0-10.

To engage students and prevent them from becoming merely passive recipients during the lecture, principles are derived from action-based learning concepts (Naidu \& Bedgood, 2012). In the context of the following case study, we refer to a broad definition of the 'action-based learning' pedagogical approach, which includes 'all learning that is orchestrated by some activity on the part of learners' (Naidu \& Bedgood, 2012). The activities performed in this case study consisted of group discussion, hands-on activities and data collection.

\section{Literature Review}

According to the Research Information System for Mobility and Transport (FIS), which is funded and published by the Federal Ministry of Transport and Digital Infrastructure (BMVI), quality plays a 
decisive role for road users who travel by car by choice in the competition between different means of transport (FIS, 2020).

The European standard DIN EN 13816 defines and sets performance targets and measures service quality in public transport (Schellhoß et al., 2002). The standard DIN EN 13816 offers a compilation of quality criteria in public transport and of quality assurance systems. This standard outlines various quality criteria, which are dealt with in accompanying synthesis reports (Klein et al., 2006). Quality is defined by six factors: development, operation, connection, equipment, service and environmental quality.

In a 2017 empirical study by Splendid Research (Hamburg, Germany), 2,069 passengers in the 10 largest German cities were surveyed about their satisfaction with public transport. Passengers rated their overall satisfaction with the service and the range of products and services offered by the local transport companies on a scale of 1-4 (defined as 'very satisfied', 'rather satisfied', 'rather dissatisfied' and 'very dissatisfied'). A total of $71.6 \%$ of those surveyed were satisfied (very satisfied and rather satisfied) and $28.5 \%$ were dissatisfied (rather dissatisfied and very dissatisfied), with $\mathrm{n}=2,028$. Other studies dealing with satisfaction with public transport include those by Stradling et al. (2007), Fellesson and Friman (2008), Del Castillo and Benitez (2013), Imam (2014), Thomaz et al. (2016) and the annual study of the Public Transport Council, Singapore, on the public transport customer satisfaction (PTC, 2020).

Mobility in Germany (MiD) is a nationwide survey of daily traffic behaviour commissioned by the BMVI. The latest study was conducted in 2017. The central aim of the study is to obtain representative and reliable information on the sociodemographics of individuals and households and their everyday traffic (e.g. routes travelled for a various purposes and modes of transport) for a whole year. It serves, weighted and extrapolated, as a framework and supplement for other traffic surveys, such as traffic surveys in individual cities. The MiD study also provides the up-to-date information on important factors influencing mobility and forms the basis for traffic models (MiD, 2019). The 2017 MiD opened up a new perspective by including questions that solicited the respondents' subjective assessment of different types of transportation and individuals' personal tendencies. The popularity of the car is clearly indicated in the survey, with an approval rate of $77 \%$, whereas public transport is rated significantly worse at $34 \%$ (MiD, 2019). What is interesting here is the approximate agreement with the results of the MiD with the results of this study for the car user group.

The EU-funded project 'Climate-friendly employee mobility' at the Institute for Management and Innovation at the University of Applied Sciences Ludwigshafen is looking into the question of what effective options are available to make climate-friendly mobility options more attractive to habitual car users. This includes not only public transport but also cycling mobility and car-sharing concepts, with the goal of enticing a significant proportion of regular car users will be able to switch over permanently. This study is particularly important because of its broad database of almost 15,000 participants (Tachkov, 2018; Tachkov \& Gregor, 2019).

\section{Methodology}

The starting point for this research project was a discussion about the new construction of a university building on the campus of the Ludwigshafen University of Applied Sciences. With an estimated cost of 67 million euro, construction on the so-called C-Building began in November 2019 on an area of 14,000 $\mathrm{m}^{2}$ (HWG LU, 2019). As this area had previously been used as a large parking lot, finding a parking space in the area around the university became a particular challenge for all university members, because there was no adequately large replacement area for parking nearby. Tardiness due to looking for a parking spot had become a frequent phenomenon on campus. This lecturer's suggestion that students use public transport was not successful, either. The reasons given by students were manifold, ranging from complaints about public transport not running on time and offering poor connections to inflexibility and inconvenience. They would essentially rather travel by car, even knowing that they would have to search for a parking space. The consensus amongst the students was that individual transport with a car was still of a significantly higher quality than public transport. This gave rise to the idea of determining this difference in quality in concrete terms. 
During the conversation with course participants, it became clear that because of the complexity and multitude of relevant factors, it was preferable to use a simple approach similar to the NPS concept. General satisfaction with the use of a means of transport would be measured on a scale of 10 . The two sides of the spectrum were placed at 0 for 'terrible' and 10 for 'very pleasant'. No designations were given for the intermediate levels $1-9$.

Two hypotheses were formulated:

1. For people who prefer individual transport by car, the quality level of using a car is significantly higher than that using a public transport.

2. For people who prefer public transport, the quality level of using public transport is roughly equivalent to using a private car.

The gap between both quality levels was called the 'Individual Transport Mobility Gap (ITMG)'. The hypotheses stated above thus correspond to a relatively large ITMG for car users and a low ITMG for public transport users.

To examine these hypotheses, suitable questions were formulated by several discussion groups. In order to gather as many responses as possible and to avoid participant drop-outs during the questionnaire, the survey was limited to six questions (and was thus nicknamed the 'six-pack-survey').

An online survey based on SAP Qualtrics (www.qualtrics.com) was chosen. To guide students to handon activities according to the action-based learning concept, one student from the course agreed to do the programming of the questionnaire with Qualtrics. The survey was reviewed and revised with pretests in the classroom.

After the final version of the questionnaire was completed (including a translation into English), a link was created to access the survey. The link was sent by email to various mailing lists and was posted on social media outlets. During the period from 29 October 2019 to 26 February 2020, a total of 969 data sets were gathered. In the first survey conducted, $n=519$ answers were collected through 23 December 2019. At the same time, the survey was also sent to partner universities to solicit international comparisons. A second round of the survey was conducted through 12 February 2020, yielding an additional 450 responses. Given the means by which data were collected, the survey can be said to have the character of a convenience sample (Maurer \& Jandura, 2009). Response rates were not calculated this would have been impractical because participation was solicited via social media such as Twitter, Facebook or Instagram.

On the basis of the period of data collection, it can be concluded that the data were collected without the influence of the 2020 corona crisis. As of 18 March 2020, Germany has no curfews, unlike countries such as Belgium or Spain. Local public transport is largely maintained (Deutsche Bahn, 2020), but timetables are being restricted in many places because of school and day nurseries closures (RBB24, 2020). As the study focuses on two particular target groups - car users and public transport users - the data set was first adjusted to eliminate responses that did not correspond to the target groups, for example, bicycle users.

After adjusting the raw data set, the remaining data set consisted of 578 car users and 173 public transport users, for a total of 751 . In relative terms, $77 \%$ of the respondents were car users (578 of 751 ) and $23 \%$ were public transport users (173 of 751). This is an intriguing result, given the fact that the data set corresponds closely to the distribution that has been empirically proven in other studies, with individual transport at $75 \%$ and public transport at 20\% (Umweltbundesamt, 2020).

Before further evaluation, the data were validated. In this case, 44 data sets were filtered out in which at least the two important questions for assessing the quality level of both transport modes and the question of professional status were not answered. After validation, 707 data sets remained (Table 1) as $\mathrm{N}_{\mathrm{CPT}}$, were divided into $537(76 \%)$ car users (data set $\mathrm{N}_{\mathrm{Car}}$ ) and $170(24 \%)$ public transport users (data set $\mathrm{N}_{\mathrm{PT}}$ ). 
Table 1. Validation of raw data set (Source: author's compilation)

\begin{tabular}{|c|c|c|c|c|c|c|}
\hline $\begin{array}{l}\text { Transport } \\
\text { mode }\end{array}$ & & Car user & $\begin{array}{l}\text { Public } \\
\text { transport User }\end{array}$ & Other & Undecided & $\begin{array}{l}\text { Survey not } \\
\text { finished }\end{array}$ \\
\hline & Sum: & $\begin{array}{l}\text { Private car, } \\
\text { car sharing, } \\
\text { carpool }\end{array}$ & $\begin{array}{l}\text { Bus, suburban } \\
\text { train, train }\end{array}$ & $\begin{array}{l}\text { Bicycle, walk, } \\
\text { scooter }\end{array}$ & $\begin{array}{l}\text { Defined as using no one } \\
\text { type exclusively or } \\
\text { mostly }\end{array}$ & \\
\hline Quantity & 969 & 578 & 173 & 84 & 85 & 37 \\
\hline in $\%$ & $100 \%$ & $59.6 \%$ & $17.9 \%$ & $8.7 \%$ & $8.8 \%$ & $3.8 \%$ \\
\hline Quantity & 751 & 578 & 173 & - & - & - \\
\hline in $\%$ & $100 \%$ & $77 \%$ & $23 \%$ & - & - & - \\
\hline Not valid & .1 .44 &.$/ .41$ & .1 .3 & - & - & - \\
\hline Quantity & $707\left(\mathrm{~N}_{\mathrm{CPT}}\right)$ & $537\left(\mathrm{~N}_{\mathrm{Car}}\right)$ & $170\left(\mathrm{~N}_{\mathrm{PT}}\right)$ & - & - & - \\
\hline in $\%$ & $100 \%$ & $76 \%$ & $24 \%$ & - & - & - \\
\hline
\end{tabular}

The questionnaire was as short as possible to attain a high degree of data quality: the longer an online survey is, the higher the risk that the respondent terminates the survey before completion (drop out), which renders the entire data set unusable for analysis. The mean value of the duration for answering the questionnaire was $3.5 \mathrm{~min}$ for $\mathrm{N}_{\mathrm{CPT}}$, although the questionnaire contained only six relevant and easy answerable questions. The average response time per question would, therefore, be about $35 \mathrm{~s}$. This is a valuable indication for the general design of online questionnaires. Assuming that a participant takes about $5 \mathrm{~min}$ to answer the questionnaire, this should limit the number of questions to about nine $(300 \mathrm{~s} / 35 \mathrm{~s})$.

It should also be mentioned that the group of public transport users $\mathrm{N}_{\mathrm{PT}}$ took about $24.4 \mathrm{~s}$ per question, meaning that they had a much lower average response time than the group $\mathrm{N}_{\mathrm{Car}}$, at about $38.7 \mathrm{~s}$ per question.

To keep the questionnaire short, typical demographic details such as gender and age were not collected. However, professional status was surveyed at the beginning of the questionnaire. This question was asked following the assumption that there are differences in the assessment of quality levels between trainees (students, apprentices and pupils) and working employees. Reasons for this could include age (trainees tend to be younger, whereas employees tend to be older), income level (trainees tend to have lower wages, whereas employees tend to have higher incomes) or time available for mobility (trainees tend to have more time available to them compared to working professionals). As expected, the $\mathrm{N}_{\mathrm{CPT}}$ sample mainly consisted of individuals in training $(\mathrm{n}=173 ; 24 \%)$ and employed persons $(\mathrm{n}=523,74 \%)$. In the group of car user $\mathrm{N}_{\mathrm{Car}}$, there were 101 persons in training (19\%) and 427 employed individuals $(80 \%)$. In the group of public transport users $\mathrm{N}_{\mathrm{PT}}$, the distribution was much more balanced, with 72 (42\%) still completing their education and 96 persons (56\%) employed.

Depending on the main mode of transport used (car or public transport), the survey split into both target groups, establishing two clear categories: $\mathrm{N}_{\mathrm{Car}}(\mathrm{n}=537)$ and $\mathrm{N}_{\mathrm{PT}}(\mathrm{n}=170)$. Regardless of the choice of mode of transport, the same four questions were asked for both target groups:

1. How many days per week (Monday to Sunday) do you use the car/public transport?

2. How long is your average travel time per day?

3. How do you rate your car/public transport journeys on average?

4. If you had to cover the distances you normally travel by car/with public transport (bus, suburban 
train and train) with car/with public transport (bus, suburban train and train) how would you rate these trips on an average?

The quality rating was given on a scale from 0 for 'terrible' to 10 for 'very pleasant'. The rating for the quality of the preferred means of transport is called $Q_{P}$; the value for the alternative means of transport is called $\mathrm{Q}_{\mathrm{A}}$. The ITMG is calculated as the difference between $\mathrm{Q}_{\mathrm{P}}$ and $\mathrm{Q}_{\mathrm{A}}$ : ITMG $=\mathrm{Q}_{\mathrm{P}} . / \mathrm{Q}_{\mathrm{A}}$. For the group of car users, the equation is thus $\mathrm{ITMG}_{\mathrm{Car}}=\mathrm{Q}_{\mathrm{PCar}} . / \mathrm{Q}_{\mathrm{APT}}$, and for the group of public transport users, $\mathrm{ITMG}_{\mathrm{PT}}=\mathrm{Q}_{\mathrm{PPT}} . / . \mathrm{Q}_{\mathrm{ACar}}$. Mean values are used for the calculation of the ITMG (cf. Figs. 1-4).

In order to make international comparisons, respondents were also asked what country they currently live in. As this is a very simple question, it was not considered to add undue length to the brief survey. A total of 701 individuals responded to this question. As expected, the largest group was from Germany, with 593 respondents; 27 respondents were in the United States, followed by Lithuania, at a considerable distance behind with 18 . The remaining 63 respondents were distributed amongst 25 countries, each with fewer than 10 answers. As the international case numbers are very small, comparisons at a country level would not be very meaningful here. For evaluation purposes, all international responses were thus grouped together $(n=108)$ and compared with the German responses $(n=593)$.

\section{Results}

The results of this 'ex ante corona crisis' study are presented in four sections. In the first section, 'Total sample', the starting point for calculations is the total number of the two main samples $\mathrm{N}_{\mathrm{Car}}(\mathrm{n}=537)$ and $N_{\text {PT }}(n=170)$. Subsamples based on demographic information such as age, gender or income are generally created to refine the analysis of existing data. In this case, this typical demographic information was not queried in the survey. For this reason, relevant subsamples were created from the information included in the survey in order to check the meaningfulness of the overall sample. The second section, 'Partial sample car user', uses subsets from the database $\mathrm{N}_{\mathrm{Car}}(\mathrm{n}=537)$. The third section, 'Partial sample public transport user', uses subsets from the database $\mathrm{N}_{\mathrm{PT}}(\mathrm{n}=170)$. In the fourth and final section, the results from the previous sections are compared.

\section{Total sample}

The hypothesis for primary car users predicted that the quality level of using a car would be rated much higher than using public transport as an alternative.

In data set $\mathrm{N}_{\text {Car }}(\mathrm{n}=537)$, the mean quality level for using a car $\mathrm{Q}_{\mathrm{PCar}}$ was 7.0, whereas the mean quality level of using public transport as an alternative $\mathrm{Q}_{\mathrm{APT}}$ was 3.0 (cf. Figs. 1 and 2). This confirms the hypothesis. With these two values, the ITMG $\mathrm{Car}_{\mathrm{C}}$ can be calculated at 4.0 (=7.0 ./. 3.0). This also confirms the assumption that the ITMG would be relatively large.

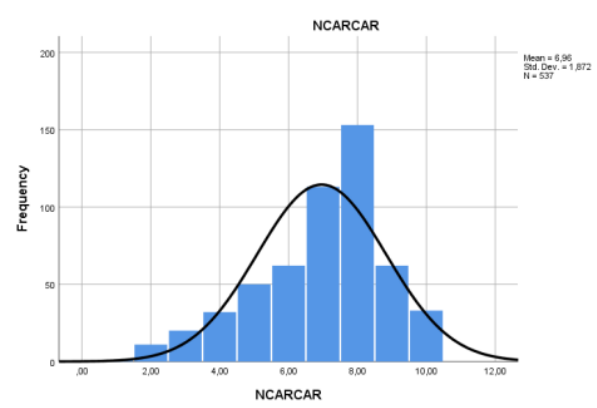

Fig. 1. Data set $\mathrm{N}_{\text {Car }}$ : $\mathrm{Q}_{\mathrm{PCar}}=7.0$ (Source: author's compilation)

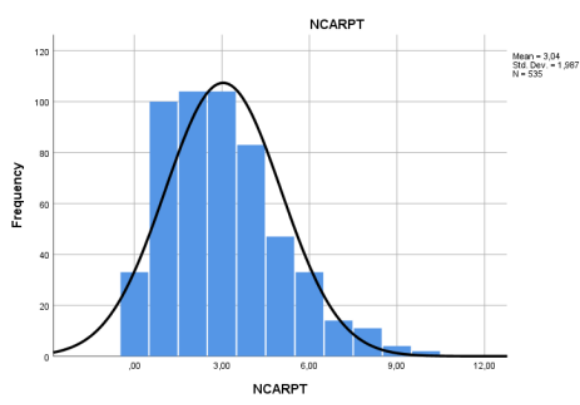

Fig. 2. Data set $\mathrm{N}_{\mathrm{Car}}$ : $\mathrm{Q}_{\mathrm{APT}}=3.0$ (Source: author's compilation) 
The hypothesis for public transport users predicted that the quality level of using a car would be roughly equivalent to using a car.

In data set $\mathrm{N}_{\mathrm{PT}}(\mathrm{n}=170)$, the mean quality level of using public transport QPPT was 6.0, whereas that of using a car as an alternative $\mathrm{Q}_{\mathrm{ACar}}$ was 5.2 (cf. Figs. 3 and 4). This hypothesis could also be regarded as confirmed. With these two values, the ITMG ${ }_{\text {PT }}$ can now be calculated at 0.8 (=6.0 ./. 5.2). This also confirms the assumption that the ITMG in this case is relatively low.

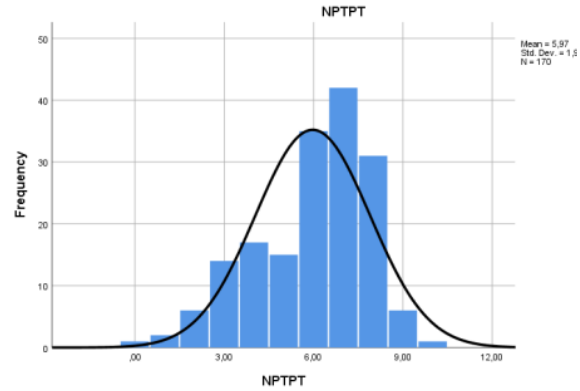

Fig. 3. Data set $\mathrm{N}_{\mathrm{PT}}$ : $\mathrm{QPPT}_{\mathrm{PPT}}=6.0$ (Source: author's compilation)

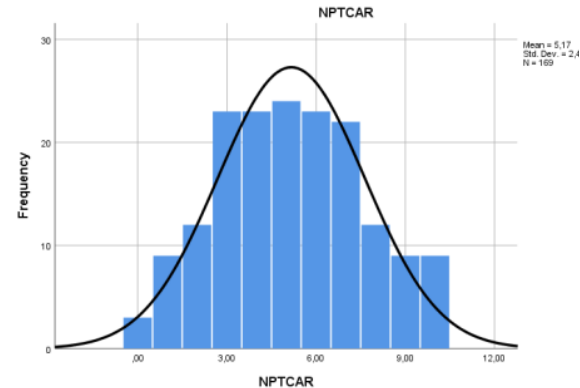

Fig. 4. Data set $\mathrm{N}_{\text {Car }}$ : $\mathrm{Q}_{\mathrm{ACar}}=5.2$ (Source: author's compilation)

Figure 5 shows the key findings from the two main samples $\mathrm{N}_{\text {Car }}$ and $\mathrm{N}_{\text {Рт. }}$. People who prefer individual transport by car had a quality rating of 7.0 (Q $\mathrm{Q}_{\mathrm{PCar}}$ ). The rating of the alternative use of public transport was far lower, at only 3.0 ( $\left.\mathrm{Q}_{\mathrm{APT}}\right)$. Their $\mathrm{ITMG}_{\mathrm{Car}}$, calculated with $\mathrm{Q}_{\mathrm{PCar}} . / . \mathrm{Q}_{\mathrm{APT}}$ was, therefore, 4.0. Compared to people mainly using public transport, public transport users rate the mean quality of their preferred mode of transport slightly lower than car users, at 6.0 (QPPT). When asked to rate the quality of driving by car as an alternative, primary public transport users gave this option an average of 5.2 $\left(\mathrm{Q}_{\mathrm{ACar}}\right)$, resulting in an $\mathrm{ITMG}_{\mathrm{PT}}$ of only 0.8; calculated with $\mathrm{Q}_{\mathrm{PPT}}$./. $\mathrm{Q}_{\mathrm{ACar}}$.

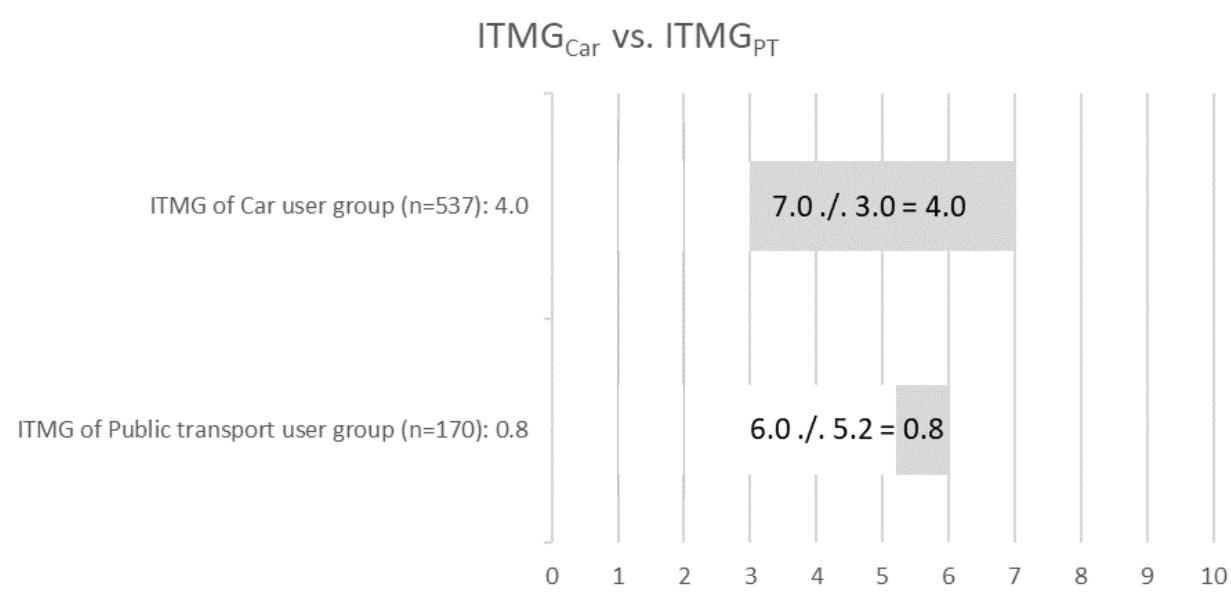

Fig. 5. ITMG $_{\text {Car versus ITMG }}$ (Source: author's compilation) 
Partial sample car user

The starting point for the formation of partial samples in this section was the database $\mathrm{N}_{\text {Car }}$, with 537 data sets (Table 2).

Table 2. Definition of Partial Samples for Car Users (Source: author's compilation)

\begin{tabular}{|c|c|c|c|}
\hline & Variable & Attribute 1 & Attribute 2 \\
\hline \multirow[t]{3}{*}{ Partial Sample } & Professional Status & Training & Employed \\
\hline & Quantity & 101 & 427 \\
\hline & $\mathrm{ITMG}=\mathrm{Q}_{\mathrm{P}} . / . \mathrm{Q}_{\mathrm{A}}$ & $4.5=7.6 . / .3 .1$ & $3.8=6.8 . / .3 .0$ \\
\hline \multirow[t]{3}{*}{ Partial Sample } & Usage & $\begin{array}{ll}\text { Light } & \text { user } \\
\text { (1-3 days a week) }\end{array}$ & $\begin{array}{ll}\text { Heavy } & \text { user } \\
\text { (4-7 days a week) }\end{array}$ \\
\hline & Quantity & 37 & 499 \\
\hline & $\mathrm{ITMG}=\mathrm{Q}_{\mathrm{P}} . / . \mathrm{Q}_{\mathrm{A}}$ & $3.4=6.7 . / .3 .3$ & $4.0=7.0 . / .3 .0$ \\
\hline \multirow[t]{3}{*}{ Partial Sample } & $\begin{array}{ll}\text { Average } & \text { daily } \\
\text { travel time } & \end{array}$ & $\begin{array}{l}\text { Short } \\
\text { (up to } 60 \text { minutes) }\end{array}$ & $\begin{array}{l}\text { Long } \\
\text { (61 to more than } 120 \text { minutes }\end{array}$ \\
\hline & Quantity & 393 & 144 \\
\hline & $\mathrm{ITMG}=\mathrm{Q}_{\mathrm{P}} . / . \mathrm{Q}_{\mathrm{A}}$ & $3.8=7.0 . / .3 .2$ & $4.3=6.8 . / .2 .5$ \\
\hline \multirow[t]{3}{*}{ Partial Sample } & Country & Germany & Internationals \\
\hline & Quantity & 455 & 82 \\
\hline & ITMG $=Q_{P} . / . Q_{A}$ & $4.0=6.9 . / .2 .9$ & $3.2=7.2 . / .4 .0$ \\
\hline
\end{tabular}

Partial sample public transport user

The starting point for the formation of partial samples in this section was the database $\mathrm{N}_{\mathrm{PT}}$, with 170 data sets (Table 3).

Table 3. Definition of Partial Samples for Public Transport Users (Source: author's compilation)

\begin{tabular}{|c|c|c|c|}
\hline & Variable & Attribute 1 & Attribute 2 \\
\hline \multirow[t]{3}{*}{ Partial Sample } & Professional Status & Training & Employed \\
\hline & Quantity & 72 & 96 \\
\hline & $\mathrm{ITMG}=\mathrm{Q}_{\mathrm{P}} . / . \mathrm{Q}_{\mathrm{A}}$ & $-0.4=5.6 . / .6 .0$ & $1.8=6.3 . / .4 .5$ \\
\hline \multirow[t]{3}{*}{ Partial Sample } & Usage & $\begin{array}{l}\text { Light } \\
(1-3 \text { days a week })\end{array}$ & $\begin{array}{l}\text { Heavy user } \\
(4-7 \text { days a week })\end{array}$ \\
\hline & Quantity & 20 & 150 \\
\hline & $\mathrm{ITMG}=\mathrm{Q}_{\mathrm{P}} . / . \mathrm{Q}_{\mathrm{A}}$ & $1.9=6.6 . / .4 .7$ & $0.7=5.9 . / .5 .2$ \\
\hline \multirow[t]{3}{*}{ Partial Sample } & $\begin{array}{ll}\text { Average } & \text { daily } \\
\text { travel time } & \end{array}$ & $\begin{array}{l}\text { Short } \\
\text { (up to } 60 \mathrm{~min} \text { ) }\end{array}$ & $\begin{array}{l}\text { Long } \\
(61 \text { to }>120 \mathrm{~min}\end{array}$ \\
\hline & Quantity & 98 & 72 \\
\hline & $\mathrm{ITMG}=\mathrm{Q}_{\mathrm{P}} . / . \mathrm{Q}_{\mathrm{A}}$ & $0.6=6.0 . / .5 .4$ & $1.2=6.0 . / .4 .8$ \\
\hline \multirow[t]{3}{*}{ Partial Sample } & Country & Germany & Internationals \\
\hline & Quantity & 138 & 32 \\
\hline & $\mathrm{ITMG}=\mathrm{Qp}_{\mathrm{p}} . / . \mathrm{Q}_{\mathrm{A}}$ & $0.8=5.9 . / .5 .1$ & $0.9=6.3 . / .5 .4$ \\
\hline
\end{tabular}




\section{Results comparison}

When comparing the different subsamples with the overall sample $\mathrm{N}_{\text {Car }}$ (cf. Fig. 6), it is easy to see that deviations from the overall sample are relatively small. The following observations can be drawn:

Individuals completing their education (Professional status: 'Training') rated the quality of their car journeys at 7.6 (QPCar), which is significantly higher than that of those in employment (Professional status: 'Employed'), 6.8 (QPCar). As the alternative of public transport was rated relatively equally, with 3.1 and 3.0 $\left(\mathrm{Q}_{\mathrm{APT}}\right)$, the ITMG is significantly higher for those undergoing training $(\mathrm{ITMG}=4.5)$ than for those in employment $(\mathrm{ITMG}=3.8)$.

A comparison between German and international respondents shows that international respondents rate the alternative of public transport with $4.0\left(\mathrm{Q}_{\mathrm{APT}}\right)$ more than 1 point higher than the Germans, with 2.9 $\left(\mathrm{Q}_{\mathrm{APT}}\right)$.

\section{ITMG ${ }_{\text {Car }}$ for partial sample car user}

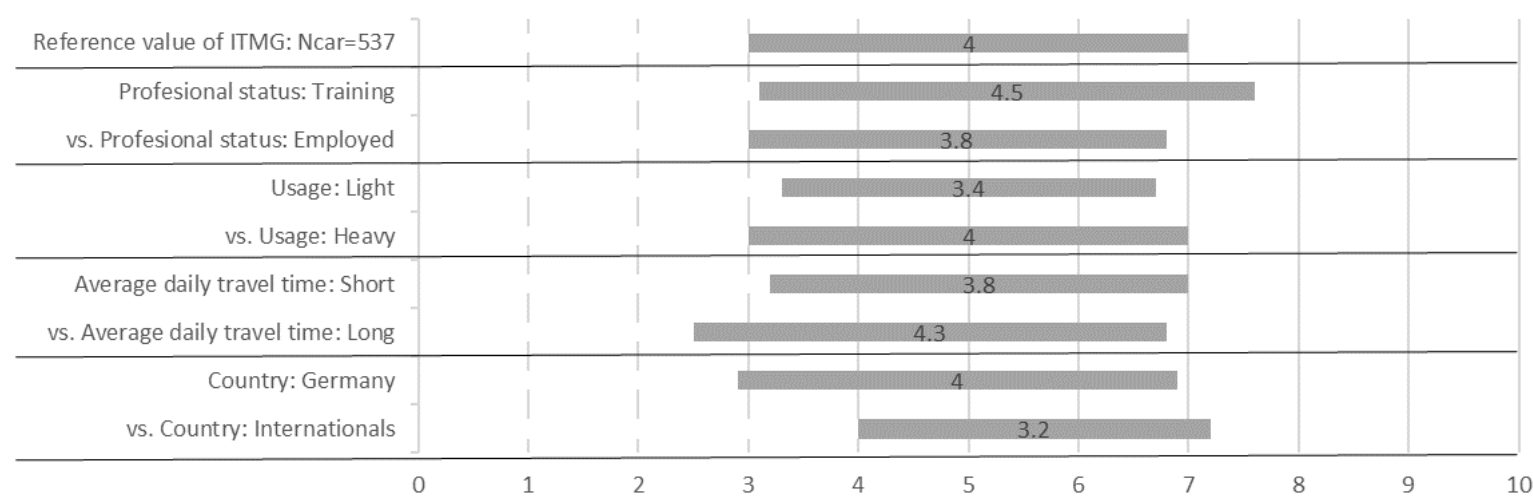

Fig. 6. ITMG $_{\mathrm{Car}}$ for Partial Sample Car User (Source: author's compilation)

The image is rather inconsistent in the $\mathrm{N}_{\mathrm{PT}}$ sample in comparison to the $\mathrm{N}_{\text {Car }}$ sample. Compared with the overall sample, their ITMGs are sometimes twice as high or even negative. The following observations can be made (Fig. 7):

The ITMG for people in training is negative, -0.4 . This means that they rate the quality of the car alternative higher than their use of public transport.

There are conspicuously high ITMGs for the subsamples 'Professional status: Employed' and 'Usage: Light' This results from the fact that both groups rated public transport highest (QPPT: 6.3 and 6.6) and, at the same time, they rated the car alternative at relatively low quality $\left(\mathrm{Q}_{\mathrm{ACar}}: 4.5\right.$ and 4.7$)$.

\section{ITMG ${ }_{P T}$ for partial sample public transport user}

Reference value: Npt=170
$\begin{array}{r}\text { Profesional status: Training > negative value } \\ \text { vs. Profesional status: Employed }\end{array}$

Fig. 7. ITMG $_{\mathrm{PT}}$ for Partial Sample Public Transport User (Source: author's compilation) 


\section{Conclusions}

Owing to the current corona crisis, status 19 March 2020, all conclusions are to be assessed as 'ex ante corona crisis' conclusions.

It must be said that this is not a representative study and the limitations of a convenience sample should be considered when evaluating the findings of this research. It is also important to note that the quality of the use of a mode of transport was examined here at a very highly aggregated level, because the survey did not ask when assessing quality what specific means of transport (e.g. specific car, bus, tram or train) the respondent was referring to.

Despite these limitations, the following conclusions can be drawn:

The results for the car users demonstrate that they see a considerable gap (ITMG) between the quality levels of car use and the alternative of public transport. It can, therefore, be concluded that one way to achieve higher rates of public transport use would be to improve the quality of public transport over car use. To do this, it would be necessary to influence the individual factors that contribute to the overall quality of a mode of transport. Important influencing factors for public transport would include, for example, network expansion, cycle times, cleanliness and ticket prices. Even this brief list shows, however, that any improvements (leading to an increase in quality) can only be achieved at great economic cost. If the goal is to improve the cleanliness of trains and buses, they would have to be cleaned more frequently and more thoroughly, and this can only be achieved with more personnel and manpower. In this respect, the allocation of additional funds for public transport could actually be a suitable means for closing the ITMG. Another way to close this gap would again be to make using private cars less attractive, for example, through higher taxes, speed limits, driving restrictions, toll systems, parking space shortages or the rededication of roads to traffic-calmed zones or bicycle lanes.

The results for those who mainly use public transport show that users rate the quality of this means of transport at one point lower $\left(\mathrm{QPPT}_{\mathrm{PP}}=6.0\right)$ than the group of car users $\left(\mathrm{Q}_{\mathrm{PCa}}=7.0\right)$. This finding points to the need to increase the quality of public transport use in order to bring it up at least to the same level of private car use.

On the basis of the results obtained, the method for determining the ITMG presented here could be a suitable method for determining the effectiveness of transport policy measures and could, therefore, be used in the implementation of specific transport investments or measures. In practical terms, a beforeand-after survey could be used to determine whether the measures taken by a city or region have had a measurable impact on usage quality by transport type, and thus on the utilisation rate of a mode of transport.

\section{Acknowledgements}

I would like to thank the undergraduate students majoring in logistics who participated in the Quality Management course during winter semester 2019-2020 at the Ludwigshafen University of Business and Society for their many interesting ideas, stimulating discussions and active participation, as well as Ms. Carly Ottenbreit for proofreading this article.

\section{References}

Bain \& Company (2011): Systematically inspiring customers. Results, (4), 3-5.

Berliner Morgenpost (2018). Busse liegen bei Ökobilanz deutlich vor Autoverkehr [Accessed 03.03.2020]. Available from Internet: https://www.morgenpost.de/berlin/article214667817/Busse-liegen-bei-Oekobilanzdeutlich-vor-Autoverkehr.html

BMVI (2020). Heute fahr ${ }^{\star}$ ich Öffis [Accessed 03.03.2020]. Available from Internet: https://www.bmvi.de/SharedDocs/DE/Artikel/K/bundesmittel-oepnv.html

Brüggemann, H. \& Bremer, P. (2015). Grundlagen Qualitätsmanagement: von den Werkzeugen über Methoden zum TQM. Wiesbaden: Springer Vieweg. 
Del Castillo, J. M., \& Benitez, F. G. (2013). Determining a Public Transport Satisfaction Index from User

Experience. Transport Policy, 14, 283-292. http://dx.doi.org/10.1016/j.tranpol.2007.02.003

Deutsche Bahn (2020). Presse-Blog zur aktuellen Lage Coronavirus und Bahnverkehr [Accessed 18.03.2020]. Available from Internet: https://www.deutschebahn.com/de/presse/pressestart_zentrales_uebersicht/Presse-Blogzur-aktuellen-Lage-Coronavirus-und-Bahnverkehr-4966788

Fellesson, M., \& Friman, M. (2008). Perceived Satisfaction with Public Transport Service in Nine European Cities. Journal of the Transportation Research Forum, 47(3), 93-103.

FIS (2020). Qualität des ÖPNV [Accessed 03.03.2020]. Available from Internet: https://www.forschungsinformationssystem.de/servlet/is/237092/

Frankfurter Allgemeine Zeitung (FAZ) (2020). Erstes Land der Welt führt kostenlosen ÖPNV ein [Accessed 03.03.2020]. Available from Internet: https://www.faz.net/aktuell/wirtschaft/auto-verkehr/luxemburg-fuehrtkostenlosen-oepnv-ein-16657094.html

HWG LU (2019). Spatenstich für den Neubau. Flyer zur Festveranstaltung am 08.11.2019.

Imam, Rana. (2014). Measuring Public Transport Satisfaction from User Surveys. International Journal of Business and Management. (9), 106-114.

Klein, A. \& Heußner, J. et al. (2006). Hinweise für die Qualitätssicherung im ÖPNV. Köln: FGSV Verlag.

Maurer, M. \& Jandura, O (2009). Masse statt Klasse? Einige kritische Anmerkungen zu Repräsentativität und Validität von Online-Befragungen, 61-73. In Jackob, N.; Schoen, H.; Zerback, T. (Eds.). Sozialforschung im Internet - Methodologie und Praxis der Online-Befragung. Berlin, Heidelberg: Springer.

MiD (2019). Mobilität in Deutschland-MiD: Ergebnisbericht. zufrieden sind die Deutschen mit dem öffentlichen Personennahverkehr. Bonn.

Naidu S., Bedgood D.R. (2012). Action-Based Learning. In: Seel N.M. (Eds.) Encyclopedia of the Sciences of Learning. Boston, MA: Springer.

PCT (2020). Surveys [Accessed 03.03.2020]. Available from Internet: https://www.ptc.gov.sg/research/surveys

RBB24 (2020). BVG schränkt Fahrpläne wegen Coronavirus ein [Accessed 19.03.2020]. Available from Internet: https://www.rbb24.de/panorama/thema/2020/coronavirus/beitraege/bvg-fahrplan-aenderung-corona-virus-krisebahn-bus.html

Schallaböck, O. \& Carpantier, R. (2012). Umweltbegleitforschung für PWK und leichte Nutzfahrzeuge: Auswahl der Vergleichsfahrzeuge Teilbericht im Rahmen der Umweltbegleitforschung Elektromobilität im Förderschwerpunkt „Modellregionen Elektromobilität“ (FKZ 03KP5003), 19.

Schellhoß, O. \& Hambuch, J. \& Nickel, B.E. (2002). Europäische Norm für Qualität im öffentlichen Personennahverkehr. Der Nahverkehr, (11), 40-45.

Splendid Research (2017). Wie zufrieden sind die Deutschen mit dem öffentlichen Personennahverkehr. Hamburg.

Stradling, S., Carreno, M., Rye, T., \& Noble, A. (2007). Passenger Perceptions and Ideal Urban Bus Journey

Surveys. Transportmetrica A: Transport Science, 9(8), 713-741.

Tachkov, P. \& Gregor, A. (2019). Projekt Klimafreundliche Mitarbeitermobilität Mobilitätsbedürfnisse im Fokus - die Praxis im Blick. Projektbericht. Hochschule für Wirtschaft und Gesellschaft Ludwigshafen, Institut für Management und Innovation.

Tachkov, P. (2018). Von der genauen Kenntnis der Kundenbedürfnisse zu verbesserten Angeboten im ÖPNV. Nahverkehrspraxis, (11/12), 40-42.

Thomaz, Paulo \& Nogueira, Carolina \& Coelho, Leonardo \& de Azambuja, Ana \& Leite Dias de Mattos, Viviane. (2016). Satisfaction with public transport: the case of an university access. International Journal of Engineering Research and Applications. (6), 2248-9622.

Umweltbundesamt (2020). Fahrleistungen, Verkehrsaufwand und „Modal Split“ [Accessed 03.03.2020]. Available from Internet: https://www.umweltbundesamt.de/daten/verkehr/fahrleistungen-verkehrsaufwandmodal-split\#fahrleistung-im-personen-und-guterverkehr

Zollondz, H.-D. (2006). Lexikon Qualitätsmanagement: Handbuch des modernen Managements auf Basis des Qualitätsmanagements. Berlin; Boston: De Gruyter Oldenbourg. 